\title{
THE EFFECTIVENESS OF INDIGENOUS ENDOMYCORRHIZA AND RHIZOBIUM INOCULUM IN INCREASING NUTRIENT UPTAKE AND YIELD OF SOYBEAN IN DRY LAND
}

\author{
Yosni Kiuk, I Nyoman Rai*, and Anak Agung Istri Kesumadewi \\ Master Program in Dryland Agriculture, Faculty of Agriculture, Udayana University \\ Jl. PB. Sudirman, Denpasar 80232, Bali \\ *Coressponding author: rainyoman@unud.ac.id
}

\begin{abstract}
Increasing the productivity of soybeans in dry land can be done by designing a package of fertilizer technology based on biological materials using indigenous endomycorrhiza and Rhizobium. The application of indigenous endomycorrhizal biofertilizer combined with Rhizobium is expected to be able to improve nitrogen and phosporus uptake so as to increase the productivity of soybeans in dry land. The experiment used two-factor factorial randomized block design. The first factor was dose of endomycorrhizal spores of Glomus that consisted of four levels, namely, treatment without endomycorrhiza inoculation, dose of 50 endomycorrhizal spores, dose of 100 endomycorrhizal spores, and dose of 150 endomycorrhizal spores. The second factor was inoculation of Rhizobium inoculum that consisted of two levels, namely, treatment without Rhizobium inoculation and Rhizobium inoculation. The results showed that combination of 50 endomycorrhizal spores with Rhizobium inoculation gave the best effect on the number of effective root nodules per plant, endomycorrhizal infection per plant, nutrient uptake by plant, number of pods per plant, number of seeds per plant, and oven-dry weight of seeds per plant.
\end{abstract}

Keywords: Endomycorrhiza, Rhizobium inoculum, Nutrient uptake, Soybean, Dry land

\section{INTRODUCTION}

Soybean is one of the important sources of vegetable protein for the people of Indonesia. The high protein content reaches $34.9 \%$ and also the content of other nutrients, such as fat, vitamins and minerals, make soybeans highly needed by the Indonesian people as an important food source in the daily diet in the form of processed culinary product (Winarto, 2010; Nugroho, 2007).

The large benefit of soybean as a food source causes the demand for soybeans in Indonesia to be high. Demand for soybeans in Indonesia reached more than 3 million tons in 2015 (Kompas, 2016). Aldillah (2015) stated that soybean consumption in Indonesia would certainly continue to increase every year. In 2015, Kompas Daily (2016) informed that the demand for soybean in Indonesia reached more than 3 million tons, but national soybean production was only 963.18 thousand tons of dried beans, so to meet the soybean demand, the government had to import soybeans as much as 2.26 million tons. 
Soybean productivity in Indonesia is classified as low at only 1.42 tons $\mathrm{ha}^{-1}$, while various research results indicate the potential for soybean productivity to reach 2 tons $\mathrm{ha}^{-1}$. Low productivity of soybean is influenced by cultivation activities that are mostly carried out on sub-optimal land, such as dry land, acidic land, and tidal wetland, and by less optimal cultivation techniques. Soybean cultivation on sub-optimal land still largely encounters a number of classic problems, such as the availability of ground water and low soil fertility that can have an impact on crop production (Khalimi and Kusuma, 2018).

The availability of essential nutrients like phosphorus $(\mathrm{P})$ and nitrogen $(\mathrm{N})$ often becomes an obstacle to the productivity of soybeans in dry land. Farmers try to increase soil fertility by using inorganic fertilizers, but inorganic phosphate fertilization turns out to be less efficient, because from the phosphate fertilizer that is used, only $\leq 30 \%$ can be absorbed by plants. The urea fertilizer applied is mostly evaporated and washed and thus, the design of a bio-based fertilizer application technology can be used as an alternative solution to the problem of low soybean productivity in dry land. Microorganisms that can be used as biological fertilizers include endomycorrhizae and Rhizobia.
Yusriadi et al. (2018) stated that applying endomycorrhiza to marginal land such as dry land is one method to increase the carrying capacity of the soil to plant growth. Endomycorrhiza is known to be associated with $80 \%$ of plants and although many fungi can act as mycorrhizae, each strain of endomycorrhiza has different abilities in increasing plant growth (Tian et al., 2004). Thus, mycorrhizal isolates that are truly compatible with cultivated plants are selected to ensure the success of endomycorrhiza inoculation (Prafithriasari and Nurbaity, 2010). The use of indigenous endomycorrhizae is also expected to provide a higher level of success, bearing in mind that the indigenous endomycorrhiza has the ability to adapt to the local environment so that the success of inoculation of indigenous endomycorrhiza is expected to be better than that of exogenous endomycorrhiza. The use of endomycorrhizae also optimize the application of phosphorus fertilizer and can support the uptake of nutrients needed for plants to increase growth and production.

Meanwhile, Rhizobium has long been known to associate with soybean plants by helping to fix nitrogen $(\mathrm{N})$ from the air. Every kilogram of nitrogen fixed in root nodules is equivalent to $2.22 \mathrm{~kg}$ of urea fertilizer (urea contains $45 \%$ nitrogen) so that it can save the use of synthetic nitrogen fertilizer (Husin, 2012). Sari and 
Prayudyaningsih (2015) further stated that Rhizobium was able to meet $80 \%$ of the nitrogen intake of legume and increase production between $10 \%-25 \%$, where the results varied greatly depending on plant response and soil conditions and the effectiveness of Rhizobium populations.

The influence of double inoculation of Rhizobium and mycorrhiza on the growth of soybean plants on dry land has not been much studied. Interactions between microbes in the soil can be synergistic and can also be antagonistic. This study was conducted to determine the combination of the effects of inoculations of indigenous endomycorrhiza and Rhizobium inoculum, which are expected to be able to improve nitrogen and phosphorus uptake, which in turn can increase soybean crop productivity in dry land.

\section{MATERIALS AND METHODS}

This study was conducted from May to November 2019. The Greenhouse Experiment was carried out in the Experimental Garden of the Faculty of Agriculture, Udayana University, by using two-factor Randomized Block Design (RCBD). The first factor was dose of endomycorrhizal spores of Glomus that consisted of four levels, namely, $\mathrm{D}_{0}=$ treatment without endomycorrhiza inoculation, $\mathrm{D}_{1}=$ dose of 50 spores, $\mathrm{D}_{2}=$ dose of 100 spores, and $\mathrm{D}_{3}=$ dose 150 spores. The second factor was Rhizobium inoculum that consisted of two levels, namely, $\mathrm{R}_{0}=$ treatment without inoculation, and $\mathrm{R}_{1}=$ Rhizobium inoculation .

This study was initiated by isolating endomycorrhizal spores in the Laboratory of Genetic Resources and Molecular Biology at Udayana University using the wet sieving method based on the instructions that were proposed by Brundrett et al. (1996). Soil samples were obtained from the rhizosphere of corn plants in the lowlands (with an altitude of $<400$ meters above sea level) in Gianyar Regency, Bali. This step was conducted based on the results of Ke Lele $e t$ al. (2018) who informed that endomycorrhizal spores from exploration in the lowlands of Gianyar Regency had more ability in sporulation than those in the medium and highlands. Isolated spores were identified to determine the endomycorrhiza genus based on guidelines according to INVAM (2017). Furthermore, the identified spores were placed in carrier media in the form of zeolites with spore density in accordance to treatment.

The planting media used were alfisols (based on a map of soil types in the Province of Bali) that were obtained from the Bukit Jimbaran area, Badung Regency, Bali. Meanwhile, soybean seeds that were used in 
this study were Dena-1 variety of soybeans obtained from the Indonesian Legumes and Tuber Crops Research Institute (BALITKABI), Malang, East Java Province. Seeds that got Rhizobium inoculation treatment were mixed with Rhizobium inoculum that was obtained from the Microbiology Laboratory, Faculty of Agriculture, Gadjah Mada University, at a dose of $10 \mathrm{~g} / \mathrm{kg}$ of seed. Planting and application of endomycorrhiza were conducted using layered system.

The variables observed in this study were number of pods per plant, number of seeds per plant, oven-dry weight of seeds per plant, number of effective root nodules per plant, and maximum nutrient uptake of nitrogen $(\mathrm{N})$ and phosphorus $(\mathrm{P})$ per plant, which was preceded by measurements of soybean tissue nutrient compositions at the end of the generative phase. Measurements were conducted using alkaline ashing methods with $\mathrm{HNO}_{3}$ and $\mathrm{HClO}_{4}$ for determination of phosphorus content in tissue, using the Kjeldahl method for determination of nitrogen content, and using clearing methods $(\mathrm{KOH} 10 \%)$ and staining ( $0.05 \%$ trypan blue) to determine the rate of root infection by endomycorrhiza. The rate of endomycorrhizal infection was calculated using the Grid Line Intersection method of Brundrett et al. (1996).
Data analysis of observations employed analysis of variance (ANOVA). If the interaction has a significant effect, then further test with Duncan's multiple range test is performed. Meanwhile, if the interaction is not significantly different, then the test of the influence of a single factor is conducted by using the Least Significant Difference (LSD) test.

\section{RESULTS AND DISCUSSION}

The results showed that the interaction of doses of endomycorrhiza treatments with Rhizobium inoculation had a very significant effect on the oven-dry weight of seed per plant. The dose of 50 endomycorrhizal spores treatment that was combined with Rhizobium inoculation $\left(\mathrm{D}_{1} \mathrm{R}_{1}\right)$ resulted in the highest oven-dry weight of seeds per plant at $6.84 \mathrm{~g}$ (Table 1). This positive correlation was highly significant with the yield components, which were the number of pods per plant $(\mathrm{r}=0.99 * *)$ and the number of seeds per plant $(0.98 * *)$ with a value of 31.13 pods and 60 seeds per plant, respectively (Table 2). The number of pods and the number of seeds were also correlated very positively with the value of $r=0.97 * *$, which showed that the number of pods per plant increased so that the number of seeds per plant also increased and then would increase the yield of seed weight per plant. Dosing of 50 endomycorrhizal spores 
treatment and Rhizobium inoculation increased the number of full pods to reach $105 \%$, compared to control treatments.

Table 1. Oven-dry weight of seed per plant in doses of endomycorrhizal spores treatments and Rhizobium inoculation treatments

\begin{tabular}{ccccc}
\hline \multirow{2}{*}{ Treatment } & \multicolumn{4}{c}{ Oven-dry Weight of Seed $(\mathrm{g})$} \\
\cline { 2 - 5 } & $\mathrm{D}_{0}$ & $\mathrm{D}_{1}$ & $\mathrm{D}_{2}$ & $\mathrm{D}_{3}$ \\
\hline $\mathrm{R}_{0}$ & $4.05 \mathrm{c}$ & $4.25 \mathrm{c}$ & $4.22 \mathrm{c}$ & $4.19 \mathrm{c}$ \\
$\mathrm{R}_{1}$ & $4.27 \mathrm{c}$ & $6.84 \mathrm{a}$ & $6.66 \mathrm{ab}$ & $6.06 \mathrm{~b}$ \\
\hline
\end{tabular}

Annotation: Numbers followed by different letters show a significant difference in Duncan's multiple range test at 5\% significance level.

Table 2. Number of pods and number of seeds per plant in doses of endomycorrhizal spores treatments and Rhizobium inoculation treatments

\begin{tabular}{ccccccccc}
\hline \multirow{2}{*}{ Treatment } & \multicolumn{4}{c}{ Number of Pods } & \multicolumn{4}{c}{ Number of Seeds } \\
\cline { 2 - 9 } & $\mathrm{D}_{0}$ & $\mathrm{D}_{1}$ & $\mathrm{D}_{2}$ & $\mathrm{D}_{3}$ & $\mathrm{D}_{0}$ & $\mathrm{D}_{1}$ & $\mathrm{D}_{2}$ & $\mathrm{D}_{3}$ \\
\hline $\mathrm{R}_{0}$ & $15.13 \mathrm{c}$ & $16.75 \mathrm{c}$ & $17.00 \mathrm{c}$ & $15.75 \mathrm{c}$ & $31.50 \mathrm{f}$ & $36.00 \mathrm{def}$ & $34.63 \mathrm{def}$ & $33,13 \mathrm{ef}$ \\
$\mathrm{R}_{1}$ & $19.13 \mathrm{c}$ & $31.13 \mathrm{a}$ & $27.63 \mathrm{ab}$ & $25.50 \mathrm{~b}$ & $39.88 \mathrm{~cd}$ & $60.00 \mathrm{ab}$ & $56.00 \mathrm{ab}$ & $50,63 \mathrm{~b}$ \\
\hline
\end{tabular}

Annotation: Numbers followed by different letters show significant difference in Duncan's multiple range test at $5 \%$ significance level.

In the treatment without Rhizobium plant, the highest number of seeds per plant, inoculation $\left(\mathrm{R}_{0}\right)$, different endomycorrhizal and the highest oven-dry weight per plant in doses did not cause differences in the number the study were obtained in combination of pods per plant, number of seeds per plant, treatment of dose of 50 endomycorrhiza and oven-dry weight of seeds per plant. In spores with Rhizobium inoculation $\left(\mathrm{D}_{1} \mathrm{R}_{1}\right)$. contrast, in the Rhizobium inoculation From these phenomena, it can be concluded treatment $\left(\mathrm{R}_{1}\right)$, different endomycorrhiza that there was a synergy effect between doses caused differences in the number of endomycorrhizae and Rhizobium. In a sense, pods per plant, number of seeds per plant, the existence of endomycorrhiza will support and oven-dry weight of seeds per plant. In all rhizobial activity and similarly the existence doses of endomycorrhiza treatments, number of Rhizobium will support endomycorrhizal of pods per plant, number of seeds per plant, activity. and oven-dry weight of seeds per plant This result was in line with research increased significantly due to Rhizobium conducted by Simatupang (2018), which application. The highest number of pods per showed that the interaction of Rhizobia 
treatment with mycorrhizae significantly affected the production of peanuts, as indicated on the parameters of the number of pods per plot and the weight of seed production per plot. This result occurred because Rhizobium and mycorrhiza are both symbiotic with peanut plants. Symbiosis that occurred was mutualism symbiosis in which plants provide certain compounds that act as an energy source for endomycorrhiza and Rhizobium while mycorrhiza and Rhizobium are able to facilitate the supply of nutrients, especially nitrogen and phosphorus, for plants. Sari (2011) suggested the mechanism of tripartite relationship between endomycorrhizae, Rhizobium, and host plants, that the process of arbuscular mycorrhiza formation would increase the availability of energy, in the form of carbohydrates, for host plants so that mycorrhizal population would increase. The energy supply from the host plant will also benefit its symbiotic partner, Rhizobium. Increasing the population of Rhizobium will increase the supply of nitrogen to the host plant and its symbiotic partner, mycorrhizae. Furthermore, the supply of nitrogen to the host plant can increase the formation and translocation of photosynthates that are needed for the symbiosis of mycorrhizae with the host plant. Increased mycorrhizal and rhizobial activities, in turn, will make more nutrients flow to plants.

Table 3. Number of effective nodules and percentage of endomycorrhizal infections per plant in the doses of endomycorrhizal spore treatments and Rhizobium inoculation treatments

\begin{tabular}{|c|c|c|c|c|c|c|c|c|}
\hline \multirow[t]{2}{*}{ Treatment } & \multicolumn{4}{|c|}{$\begin{array}{c}\text { Percentage of Endomycorrhizal } \\
\text { Infections }(\%)\end{array}$} & \multicolumn{4}{|c|}{ Number of Nodules } \\
\hline & $\mathrm{D}_{0}$ & $\mathrm{D}_{1}$ & $\mathrm{D}_{2}$ & $\mathrm{D}_{3}$ & $\mathrm{D}_{0}$ & $D_{1}$ & $\mathrm{D}_{2}$ & $\mathrm{D}_{3}$ \\
\hline $\mathrm{R}_{0}$ & $9.50 \mathrm{c}$ & $66.25 b$ & $72.25 b$ & $74.75 b$ & $4.13 c$ & $4.63 c$ & $4.50 \mathrm{c}$ & $4.75 c$ \\
\hline $\mathrm{R}_{1}$ & $10.00 \mathrm{c}$ & $88.75 \mathrm{a}$ & $85.00 \mathrm{a}$ & $85.00 \mathrm{a}$ & $11.63 \mathrm{~b}$ & $23.00 \mathrm{a}$ & $21.50 \mathrm{a}$ & $21.25 \mathrm{a}$ \\
\hline
\end{tabular}

Annotation: Numbers followed by different letters show a significant difference in Duncan's multiple range test at 5\% significance level.

The effectiveness of endomycorrhizae and Rhizobium in this study was shown based on the percentage of root infection by endomycorrhiza and the number of effective root nodules formed. The results showed an interaction of endomycorrhiza doses with
Rhizobium inoculation on the rate of root infection by endomycorrhizae. In this interaction, it was seen that there was a synergy effect between endomycorrhiza and Rhizobia in increasing root infection. In treatment without Rhizobium $\left(\mathrm{R}_{0}\right)$, the 
percentage of root infection at each colonization in the roots of soybean plants. It endomycorrhiza level was only around can be clearly seen that endomycorrhiza, $66.74 \%$ in the $\mathrm{D}_{1}$ treatment and $74.75 \%$ in which was inoculated, entered the soybean the $\mathrm{D}_{3}$ treatment. Meanwhile, in Rhizobium root cells and formed structures such as inoculation treatment, the percentage of root infection at each endomycorrhiza level was around $85.00 \%$ in the $\mathrm{D}_{2}$ treatment and $\mathrm{D}_{3}$ treatment, and $88 \%$ in the D1 treatment. Furthermore, the results of the study also showed that the inoculation of Rhizobium was able to increase root infection by endomycorrhiza at each dose of endomycorrhiza treatment. In this study, the highest root infection rate was obtained in the treatment combination of the $\mathrm{D}_{1} \mathrm{R}_{1}$, which was not significantly different from the treatment combination of the $\mathrm{D}_{2} \mathrm{R}_{1}$ and the treatment combination of $\mathrm{D}_{3} \mathrm{R}_{1}$, but arbuscules, vesicles, internal hyphae in the cortex cells, and external hyphae. These structures help the growth and development of plants and each structure has different function. Arbuscules are highly branched hyphae that are formed by repeated dichotomous branching so that it resembles a tree in the host cortex cells and act as a place of exchange of nutrients needed by the host and endomycorrhizal fungi (Brundrett, 2008). Vesicles play a role in storing food reserves for endomycorrhiza, while external hyphae serve to reach areas that cannot be reached by roots to obtain nutrients significantly different from the other treatments (Table 3).

The level of endomycorrhizal infection in this study can be supported by observing the structure of soybean roots infected with endomycorrhiza after harvest. The observation was conducted in the laboratory. The results of observations in Fig. (Mohammadi et al., 2011). External hyphal spread (extraradical mycelium) of endomycoriza grows out of the cortex cells and thereby increasing the area of nutrient uptake of plants (Parniske, 2008). Thus, roots can reach more area compared to roots that are not infected with endomycorrhizae or with a low presentation of colonization. 1 show a massive endomycorrhizal 


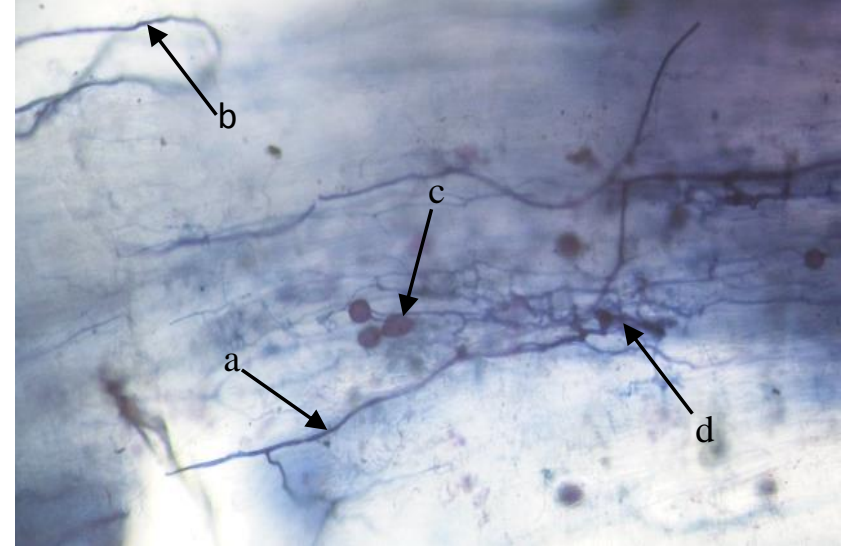

Fig. 1. Endomycorrhizal infections in soybean roots. (a) Internal hyphae; (b) External hyphae; (c) Vesicles; (d) Arbuscules. Source: Research Documentation

The doses of endomycorrhiza the number of effective nodules in $\mathrm{D}_{1}, \mathrm{D}_{2}$, treatment with Rhizobium inoculation and $\mathrm{D}_{3}$ treatments was significantly different interacted with the effective number of root nodules. The visible phenomenon was the emergence of a synergistic effect between endomycoriza and Rhizobium on the formation of effective root nodules. At the level of treatment without Rhizobium inoculation $\left(\mathrm{R}_{0}\right)$, endomycorrhiza application did not increase the number of effective root nodules. The number of effective root nodules that were formed in the treatments of $\mathrm{D}_{1}$ (dose of 50 endomycorrhizal spores), $\mathrm{D}_{2}$ (dose of 100 endomycorrhizal spores), and $\mathrm{D}_{3}$ (dose of 150 endomycorrhizal spores) was not significantly different from the number of effective root nodules that were formed in the treatment without endomycorrhiza $\left(\mathrm{D}_{0}\right)$. Meanwhile, at the level of Rhizobium inoculation treatment, endomycorrhiza application was able to significantly increase the number of effective nodules. In this case, from that in the $\mathrm{D}_{0}$ treatment. The analysis also showed that at each level of endomycorrhizal treatment, Rhizobium application caused a significant increase in the number of root nodules. In this study, the highest number of effective root nodules that was obtained in the combination of the $D_{1} R_{1}$ treatment was not significantly different from the numbers that were obtained in the $D_{2} R_{1}$ and $\mathrm{D}_{3} \mathrm{R}_{1}$ treatments, but significantly different from the numbers that were obtained in other treatments (Table 3).

The effect of synergy between endomycorrhiza and Rhizobia in increasing the number of effective root nodules can be explained by the following mechanism. The application of Rhizobia can significantly increase the formation of effective root nodules. Effective root nodules contain leghemoglobin that functions to fix nitrogen 
from the air and by the nitrogenase enzyme, legume compared to control treatments. This nitrogen is converted into ammonium, which can be absorbed by plants. The formation of has shown that the phosphorus nutrients are effective root nodules is also influenced by the availability of phosphorus nutrients. In this case, endomycorrhiza, which through external hyphae absorbs phosphorus, was not available, but becomes available and helped the formation of nodules maximally on the roots of soybean. Phosporus nutrients can be used by bacteroids as nutrients to form nodules maximally. Increasing the weight of nodules will be in accordance with the increasing number of bacteria with the ability to tether nitrogen from the air.

This is in accordance with Yakubu et al. (2010) who stated that there was an increase in the number of root nodules due to needed in the formation of nodules. The effectiveness of endomycorrhiza and Rhizobium bacteria was reflected in the parameters of the percentage of root infection and the number of effective root nodules thaw were formed, with a significant positive value $\left(\mathrm{r}=0.48^{*}\right)$. Sari (2011) stated that the increase in mycorrhizal and rhizobial populations will help increase the availability of nutrients and water for host plants, so that host plants can provide more energy to symbionts that are in the roots of the host plant. The increase in nutrients also helps the metabolic processes in plant tissue so that plants are able to form cell structures to support plant growth and development. the application of phosphorus fertilizer in the

Table 4. Maximum phosphorus nutrient uptake per plant in the doses of endomycorrhiza treatments and Rhizobium inoculation treatments

\begin{tabular}{cc}
\hline Treatment & Maximum Phosphorus Uptake $\left(\mathrm{g} \mathrm{tan}^{-1}\right)$ \\
\hline Dose of Endomycorrhizal Spores & \\
$\mathrm{D}_{0}$ & $0.020 \mathrm{c}$ \\
$\mathrm{D}_{1}$ & $0.026 \mathrm{a}$ \\
$\mathrm{D}_{2}$ & $0.023 \mathrm{~b}$ \\
$\mathrm{D}_{3}$ & $0.024 \mathrm{ab}$ \\
\hline LSD 5\% & 0.0027 \\
\hline Rhizobium Inoculation & $0.019 \mathrm{~b}$ \\
$\mathrm{R}_{0}$ & $0.028 \mathrm{a}$ \\
$\mathrm{R}_{1}$ & 0.0019 \\
\hline LSD 5\%
\end{tabular}

Annotation: Numbers followed by the same letters in the same column indicate insignificant difference in the Least Significant Difference (LSD) Test at 5\% significance level. 
Maximum phosphorus nutrient uptake per plant was the highest in the dose of 50 endomycorrhizal spores $\left(\mathrm{D}_{1}\right)$ treatment, which was not significantly different from the dose of 150 endomycorrhizal spores (D3) treatment, but significantly different from the treatment without endomycoriza $\left(\mathrm{D}_{0}\right)$ and dose of 100 endomycorrhizal spores $\left(D_{2}\right)$ treatment. Single treatment of Rhizobium inoculation (R) and Rhizobium inoculation $\left(\mathrm{R}_{1}\right)$ could significantly increase the maximum phosphorus nutrient uptake per plant (Table 4). Parameter of maximum phosphorus nutrient uptake per plant can describe the status of phosphorus nutrients of a plant because these parameters can describe how much phosphorus nutrients can be uptaken by soybeans that were treated with doses of endomycorrhiza and Rhizobium application. Based on this understanding, the $50 \%$ endomycorrhizal treatment can be considered as the treatment that has provided the highest nutrient uptake in this study. According to Baon (1998), increased nutrient uptake due to the application of endomycorrhiza occurs through several mechanisms: (1) Polyphosphate is formed in hyphae so as to maintain low internal $\mathrm{P}$ concentrations; (2) The small diameter of the hyphae produces a greater total surface area of contact with the phosphorus source compared to the root surface area; (3) Extracellular phosphatase enzymes are produced and increase the availability of $\mathrm{P}$ nutrients.

Table 5. Maximum nitrogen uptake per plant in the doses of endomycorrhizal spores treatments and Rhizobium inoculation treatments

\begin{tabular}{ccccc}
\hline \multirow{2}{*}{ Treatment } & \multicolumn{4}{c}{ Maximum Nitrogen Uptake $\left(\mathrm{g} \mathrm{tan}^{-1}\right)$} \\
\cline { 2 - 5 } & $\mathrm{D}_{0}$ & $\mathrm{D}_{1}$ & $\mathrm{D}_{2}$ & $\mathrm{D}_{3}$ \\
\hline $\mathrm{R}_{0}$ & $0.168 \mathrm{~g}$ & $0.192 \mathrm{fg}$ & $0.258 \mathrm{~d}$ & $0.234 \mathrm{de}$ \\
$\mathrm{R}_{1}$ & $0.212 \mathrm{ef}$ & $0.436 \mathrm{a}$ & $0.363 \mathrm{bc}$ & $0.326 \mathrm{c}$
\end{tabular}

Annotation: Numbers followed by different letters show significant difference in Duncan's multiple range test at $5 \%$ significance level.

The results of the study's analysis showed that at the level of treatment without Rhizobium inoculation $\left(\mathrm{R}_{0}\right)$, the most maximum nutrient uptake of plants was obtained in the dose of 100 endomycorrhizal spores $\left(D_{2}\right)$ treatment, whereas at the level of Rhizobium inoculation $\left(\mathrm{R}_{1}\right)$ treatment, the highest nitrogen consentration in plant tissue was obtained in dose of 50 endomycorrhizal spores $\left(D_{1}\right)$ treatment. The results of the next 
analyzes showed that at each fixation in the growth of legumes can be endomycorrhizal dose level $\left(\mathrm{D}_{0}\right.$ to $\left.\mathrm{D}_{3}\right)$, improved by giving double inoculants of Rhizobium application was significantly able to increase the maximum nitrogen nutrient uptake per plant (Table 5). In general, it can be seen that the combination of endomycorrhizal dose treatment and Rhizobium inoculation treatment that produced the highest nitrogen nutrient uptake per plant was the $\mathrm{D}_{1} \mathrm{R}_{1}$ treatment. The increase in nitrogen nutrient uptake in this study was inseparable from the important role of endomycorrhiza and Rhizobium in increasing nitrogen nutrient uptake. The important role of Rhizobium in increasing nitrogen nutrient uptake is evident from the process of nitrogen fixation from the atmosphere. The effectiveness of Rhizobium in fixing nitrogen from the atmosphere can be traced to the number of effective root nodules formed. The results of this study showed that the highest number of effective root nodules was obtained in treatment combination of $D_{1} R_{1}$, which was not significantly different from $D_{2} R_{1}$ and $D_{3} R_{1}$ treatments, but significantly different from other treatments.

The results of this study have proven the synergy effect of endomycorrhizae and Rhizobium in increasing nutrient uptake of soybean. This is in line with the study of Tajini and Drevon (2012), which showed that the efficiency of phosphorus and nitrogen mycorrhiza and Rhizobium. Utilization of these two microbes can further support plant growth because increased plant nutrients can form metabolic processes in plant tissues so plants are able to form cell structures to support plant growth and development.

In general, the results of this study indicated that a treatment combination of 50 endomycorrhizal spores with Rhizobium inoculation provided a better effect than other treatment combinations. It can be suspected that the increase in endomycorrhizal spore populations has caused a competitive effect between endomycorrhizae and Rhizobium. According to Hendrita et al. (2013), the infectivity and effectiveness of mycorrhizae are influenced by microbial interactions and competition between mycorrhizal fungi themselves.

\section{CONCLUSIONS}

1. The interaction between endomycorrhizal spore doses and Rhizobium inoculation had a very significant effect $(\mathrm{P}<0.01)$ on the variables of number of effective root nodules, the percentage of root infection by endomycorrhizae, nutrient uptake, number of pods, number of seeds, and oven-dry weight of seed. 
2. Compared to other treatment combinations, the treatment combination of 50 endomycorrhizal spores with Rhizobium inoculation $\left(\mathrm{D}_{1} \mathrm{R}_{1}\right)$ resulted in the highest oven-dry weight of seeds per plant $(6.82 \mathrm{~g})$.

\section{REFERENCES}

Aldillah R. (2015). Proyeksi Produksi dan Konsumsi Kedelai Indonesia 20132020. Jurnal Ekonomi Kuantitatif Terapan. 8(1): 9-23. [In Indonesian]

Baon, J. B. (1998). Mycorryhizal Symbiosis in Managing Phosphorus Efficiency in Theobroma cacao L. Enhancing Strategic Plant Physiological Research and Technologies for Sustainable Resources: 215.

Brundrett, M. (2008). Mycorrhizas in natural ecosystems. Advances in ecological research. 21: 171-313.

Brundrett, M., N. Bougher, B., Dell., T. Grave dan N. Malajezuk. (1996). Working with Mycorrizha in Forestry and Agriculture. Australian Centre for International Agriculture Research (ACIAR).Canbera.

Garg, N. dan G. Manchanda. (2008). Effect Of Arbuscular Mycorrhizal Inoculation of Salt-Induced Nodule Senescence in Cajanus Cajan (Pigeonpea). Journal of Plant Growth Regulators. 27: 115-124.

Harian Kompas. (2016). Impor Kedelai Mencapai 2,26 Juta Ton. http://print.kompas.com. Diakases Senin, 03 Maret 2019. [In Indonesian] Hendrita, T., A. Faqih dan S. Wahyuni. (2013). Pengaruh Jenis Inokulan dan Pupuk Fosfor Terhadap Pertumbuhan dan Hasil Tanaman Kacang Tanah (Arachis hypogaea L.) Kultivar Kelinci. Agrijati.24(1). [In Indonesian]
Husin, M. N. (2012). Pengaruh Pupuk Organik Cair NASA terhadap Nitrogen Bintil Akar dan Produksi Macroptilium atropurpureum. Agripet.12(2): 20-23. [In Indonesian]

INVAM. (2017). International culture collection of (Vesicular) arbuscular mycorrhizal fungi. West Virginia University, Morgantown, West Virginia. http://invam.wvu.edu/thefungi/species-descriptions.

Ke Lele, O., I N. Rai, dan K. Suada. (2018). Uji Efektivitas Beberapa Genus Endomikoriza Indigenus terhadap Pertumbuhan Tanaman Jagung (Zea mays L.). Agrotrop. 8(1): 20-27. [In Indonesian]

Khalimi, F dan Z. Kusuma. (2018). Analisis Ketersediaan Air pada Pertanian Lahan Kering di Gunungkudul Yogyakarta. Jurnal Tanah dan Sumberdaya Lahan. 5(1): 721-726. [In Indonesian]

Nugroho, D. N. (2018). Pengaruh Pemberian Cendawan Mikoriza Arbuskular dan Dosis Kompos Gulma Siam Terhadap Pertumbuhan dan Hasil Kedelai.Tesis. Universitas Mercu Buana Yogyakarta. [In Indonesian]

Mohammadi K., G. Heidari, dan Y. Sohrabi. (2011). Beneficial effects of the mycorrhizal fungi for plant growth. Applied environmental and biological sciences. 1(9): 310-319.

Prafithriasari, M dan A. Nurbaity. (2010). Infektivitas Inokulum Glomus sp. dan Gigaspora sp. Pada berbagai komposisimedia zeolit-arang sekam dan pengaruhnya terhadap pertumbuhan sorgum (Sorghum bicolar). Jurnal Agrikultura. 21(1): 39-45. [In Indonesian]

Sari, K. R. (2011). Pengaruh Mikoriza Arbuskula dan Rhizobium pada Tanaman Kacang Tanah (Arachis hypogaea) di Media Tanah Madura pada Kondisi Cekaman Kekeringan. Institut Teknologi Sepuluh Nopember, Surabaya. [In Indonesian] 
Simatupang, L. (2018). Pengaruh Pemberian Mikoriza dan Bakteri Rhizobium Terhadap Pertumbuhan dan Produksi Kacang Tanah (Arachis hypogaea L.). Tapanuli Journals. 1(1): 104-111. [In Indonesian]

Parniske, M. (2008). Arbuscular mycorrhiza: the mother of plant root endosymbioses. Focus on symbiosis. 6:763-775.

Sari, R dan R. Prayudyaningsih. (2015). Rhizobium: Pemanfaatannya Sebagai Bakteri Penambat Nitrogen. Info Teknis EBONI. 12(1): 51-64. [In Indonesian]

Tian, C. Y., G. Feng, X. L. Li, dan F. S. Zhang. (2004). Different Effects of Arbuscular Mycorrhizal Fungal Isolates from Saline or Non-Saline Soil on Salinity Tolerance of Plants. Appl. Soil Ecol. 26: 43-48.

Winarto, S. (2010). Kebutuhan kedelai Indonesia. Bogor. Departemen Budidaya Pertanian, Fakultas Pertanian. Institut Pertanian Bogor. 7(2): 17-26. [In Indonesian]

Yakubu, H., J.D. Kwari and M.K. Sandabe. (2010). Effect of Phosph orus Fertilizer on Nitrogen Fixation by Some Grain Legume Varieties in Sudan Sahelian Zone of North Eastern Nigeria. Nigerian Journal of Basic and Applied Science 18(1):1926.

Yusriadi., Y. S. Pata'dungan, dan U. Hasanah. (2018). Kepadatan dan Keragaman Spora Fungi Mikoriza Arbuskula pada Daerah Perakaran Beberapa Tanaman Pangan di Lahan Pertanian Desa Sidera. Agroland 25(1): 64-73. [In Indonesian] 